УДК 159.9.019

DOI https://doi.org/10.26661/2310-4368/2021-3-2

\title{
СОЦІАЛЬНО-ПСИХОЛОГІЧНИЙ СУПРОВІД ДІТЕЙ З ОСОБЛИВИМИ ОСВІТНІМИ ПОТРЕБАМИ В УМОВАХ ЗАКЛАДІВ СЕРЕДНЬОЇ ОСВІТИ
}

\author{
Дрозд Л. В. \\ кандидат психологічних наук, \\ викладач кафедри спеціальної освіти \\ Херсонський державний університет \\ вул. Університетська, 27, Херсон, Україна \\ orcid.org/0000-0001-5406-2942 \\ drozdlidiya301091@gmail.com \\ Лаврикова О. В. \\ кандидат біологічних наук, \\ професор кафедри спеціальної освіти \\ Херсонський державний університет \\ вул. Університетська, 27, Херсон, Украӥна \\ orcid.org/0000-0003-2757-1148 \\ o.lavrykova@ukr.net
}

Ключові слова: особливі
освітні потреби, сочіально-
психологічний супровід,
сочіалізація, учні.
Соціально-психологічний супровід розглядається як система послідовної, комплексної, соціально спрямованої діяльності команди фахівців, яка забезпечує процеси індивідуалізації особистості учня 3 особливими освітніми потребами, створює умови для його самовизначення за рахунок власних можливостей і здібностей. На основі показників ефективності соціально-психологічного супроводу та критеріїв (когнітивний, мотиваційно-ціннісний та особистіснодіяльнісний) визначено три узагальнені рівні соціалізації дітей з ООП: високий, середній i низький. Запропоновано методику соціально-

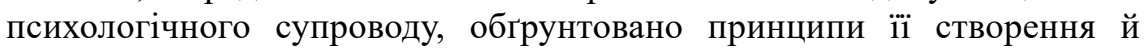
основні використанні методи, зокрема метод кейсів. Висвітлено етапи впровадження методики. Установлено показники соціалізації на початку та після впровадження експерименту. Висвітлено основну мету методики - створення психологічних умов на заняттях й у позакласній роботі для цілеспрямованого, особистісно-орієнтованого процесу формування в учнів соціальних компетентностей і м'яких технологій, що забезпечить їх успішну соціалізацію. Окремо надано опис команди супроводу та визначено основні форми іiі діяльності: діагностичну - усебічне вивчення дитини з урахуванням первинного порушення; прогностичну - визначення напрямів корекційної роботи, складання індивідуальної програми розвитку, прогнозування результатів корекційного та освітнього впливу; корекційну - упровадження особистісно орієнтованих програм навчання та реабілітації; проведення корекційно-розвивальних занять; інформаційно-консультативнопросвітницьку - своєчасне й переконливе інформування батьків, педагогічний колектив про проблеми дітей i труднощі в навчанні; тренінги підвищення кваліфікації для фахівців закладів. Методика соціально-психологічного супроводу на основі кейсів дає можливість ставити перед учнями завдання та поетапно досягати результату їх виконання за рахунок вирішення проблемної ситуації. У статті висвітлено результати реалізації методики соціально-психологічного 
супроводу дітей 3 особливими освітніми потребами. Проведено порівняльний аналіз з іншими методиками супроводу в наукових працях зі спеціальної психології та корекційної освіти.

\title{
SOCIAL AND PSYCHOLOGICAL SUPPORT OF CHILDREN WITH SPECIAL EDUCATIONAL NEEDS IN THE CONDITIONS OF SECONDARY EDUCATION ESTABLISHMENTS
}

\author{
Drozd L. V. \\ Ph.D. in Psychology, \\ Lecturer at the Department of Special Education \\ Kherson State University \\ Universytetska str., 27, Kherson, Ukraine \\ orcid.org/0000-0001-5406-2942 \\ drozdlidiya301091@gmail.com \\ Lavrykova O. V. \\ Ph.D. in Biology, \\ Professor at the Department of Special Education \\ Kherson State University \\ Universytetska str., 27, Kherson, Ukraine \\ orcid.org/0000-0002-7384-8710 \\ o.lavrykova@ukr.net
}

Key words: special educational needs, social and psychological support, socialization, students.
Social and psychological support is considered as a system of coherent, comprehensive, socially oriented activity of the team of specialists, which provides the processes of individualization of the student's personality with special educational needs, creates conditions for one's self-determination due to one's own capabilities and abilities. Based on the indicators of the effectiveness of social and psychological support and criteria (cognitive, motivational-value and personal-efficient), three generalized levels of socialization of children with special educational needs are identified: high, medium and low. The methodology of social and psychological support is offered; the principles of its creation and the main used methods, in particular, the method of cases is substantiated. The stages of the methodology implementation are highlighted. The indicators of socialization at the beginning and after the implementation of the experiment are identified. The main purpose of the method is to create psychological conditions in the class and in extracurricular activities for a purposeful, personality-oriented process of formation of students' social competencies and soft technologies, which will ensure their successful socialization. The description of the support team is given separately and the main forms of its activity are determined: diagnostic - comprehensive study of the child taking into account the primary disorder; prognostic determination of directions of correctional work, the design of the individual programme of development, prediction of results of corrective and educational influence; correctional - implementation of personality-oriented training and rehabilitation programmes; conducting of correctional and developmental classes; informational-consultative-educational - timely and convincing informing of parents about children's problems and difficulties in learning by pedagogical staff; advanced training for specialists of institutions. The methodology of social and psychological support on the basis of cases provides 
an opportunity to set tasks for students and gradually achieve the result of their implementation by solving the problematic situation. The article highlights the results of the implementation of methodology of social and psychological support of children with special educational needs. A comparative analysis with other methods of support in scientific papers on special psychology and correctional education was conducted.

Постановка проблеми. У сучасних умовах реформування системи освіти психологічний супровід дітей з особливими освітніми потребами (далі - ООП) є одним із найважливіших завдань спеціальної та інклюзивної освіти, адже мусить забезпечити комплексну психологічну підтримку й допомогу таким дітям у процесі їхнього розвитку, корекції порушень і здобуття освіти відповідного рівня з метою соціалізації - входження в суспільство на рівних правах із людиною 3 нормою розвитку. Суттєві труднощі виникають у процесі соціалізації дітей зі складними порушеннями розвитку (І. Ананьєв, Ю. Бистрова, 20021; В. Синьов, О. Хохліна, М. Матвеєва, 2008; de Verdier, 2018; Verver, Mathijs Vervloed \& Steenbergen, 2019) [1; $2 ; 8 ; 12 ; 14]$.

У сучасній спеціальній психології вчені засвідчують відносно низький рівень соціальної адаптації, сформованості життєвих планів у дітей 3 особливими освітніми потребами та вказують на неготовність до самостійного проектування власного майбутнього (А. Іваненко, 2015) [3], недостатню сформованість комунікативної та мотиваційно-вольової сфер особистості як фундаменту особистісного самовизначення й розвитку самосвідомості (В. Синьов, 2008) [8].

Учені наголошують на проблемах підготовки дітей $з$ особливими освітніми потребами на різних вікових етапах до інтеграції в соціум у контексті формування в них нормативної поведінки та моральних якостей (А. Іваненко, 2015) [3].

Особливої актуальності проблема успішної соціалізації набуває в дітей з тяжкими порушеннями розвитку внаслідок дефіцитарності, дисгармонійності або викривлення загального розвитку. У цій ситуації виникає дивергенція між біологічним і соціальним профілями розвитку та спотворюється процес соціалізації дитини. Це зумовлює необхідність упровадження соціальної та психологічної виваженої підтримки дитини 3 тяжкими порушеннями розвитку всіма суб'єктами освітнього процесу, зокрема вчителями, адміністрацією школи, психологами й соціальними педагогами, медиками та батьками (Ю. Бистрова, Л. Дрозд, 2020) [10]. Такий комплексний підхід до розвитку особистості школяра з ООП, до його успішної адаптації та соціалізації дає можливість реалізувати соціально-психологічний супровід як специфічну технологію роботи 3 дітьми.
У науковій літературі висвітлено окремі аспекти супроводу таких дітей 3 метою формування в них соціальних компетентностей (Ю. Бистрова, 2021) $[1 ; 2 ; 12]$.

У працях українських учених відображено питання методичного забезпечення процесу формування та корекції навичок навчально-практичної діяльності в дітей з ООП (Ю. Бистрова, 2021) [2]. У науковій літературі широко представлений психолого-педагогічний і медичний аспект реабілітації таких дітей $[9 ; 11 ; 12]$. Питання формування особистості дитини з ООП, окремі аспекти розвитку комунікативної діяльності й міжособистісних стосунків зазначеної категорії дітей відображено в працях Ю. Бистрової, Л. Дрозд, Д. Супрун, М. Федоренка, (2018); Stephens \& Breheny (2020) [10; 13].

Результати огляду спеціальної (М. Матвєєва, В. Синьов, О. Хохліна, 2008; I. Ананьєв, Ю. Бистрова, 2021) [1] і соціальної (С. Савченко, I. Попович, 2019) [7] науково-педагогічної літератури дали змогу уточнити зміст поняття «соціально-психологічний супровід» і виділити його особливості. У працях багатьох учених (В. Синьов, О. Пометун, В. Кривуша, М. Супрун, 2000) зазначено правовий аспект проблеми: науковці порівнюють супровід із захистом і розглядають його як систему психологічних і соціальних дій, що забезпечує фізичну, психологічну, моральну безпеку дитини в освітньому процесі та створює правову базу іiі успішної соціалізації в закладі освіти [9].

Соціально-психологічний супровід дітей 3 ООП має здійснюватися всіма суб'єктами педагогічної системи в ситуаціях взаємодії з дитиною та спрямований на пошук сильних сторін і компенсаторних механізмів розвитку дитини, корекцію, опору на збережені психічні функції та аналізатори $з$ урахуванням структури порушення й рівня психофізичного розвитку, створення соціально-психологічних умов для формування зв'язку із суспільством і формування інтегративних навиків (Н. Колодна, 2008; de Verdier, 2018) [4; 11].

Проте при всій багатоманітності й науковій цінності перелічених робіт вони не розкривають низку питань, пов' язаних із проблемою соціально-психологічного супроводу дітей з ООП в умовах закладів середньої загальної освіти. Під соціально-психологічним супроводом розуміється комплексна система засобів і методів, які забезпечують допо- 
могу дитині при необхідності прийняття власного рішення, індивідуальному виборі, при самореалізації в навчальній, комунікативній, професійно-трудовій діяльності; підтримка соціального становлення особистості під час формування в неї в процесі навчання та виховання здібностей, моральних цінностей, самосвідомості.

Мета статті полягає в науковому обгрунтуванні, розробці й експериментальній перевірці методики соціально-психологічного супроводу дітей з ООП у закладах середньої освіти.

Відповідно до поставленої мети, визначено такі завдання:

1. На основі аналізу й узагальнення наукової літератури 3'ясувати рівень соціалізації дітей 3 ООП як показника ефективності, здійснюваного в умовах закладу освіти соціально-психологічного супроводу.

2. Розробити й апробувати методику соціально-психологічного супроводу дітей з ООП у взаємодії з усіма ланками освітнього процесу.

3. Розробити й апробувати комплекс соціально-психологічних технологій організації процесу соціалізації учнів з ООП на основі кейс-методу.

Виклад основного матеріалу дослідження. Значущим показником ефективності соціально-психологічного супроводу дітей $\epsilon$ їхня успішна соціалізація. У констатувальному дослідженні виділено критерії соціалізації дітей з ООП:

когнітивний - самовизначення та ідентифікація особистості, пізнання особистістю самої себе, власних здібностей, самостійність у діяльності;

мотиваційно-ціннісний - створення особистістю власних моральних цінностей, мотивів діяльності, самосвідомості й автономності;

особистісно-діяльнісний - рівень спілкування та навчальної діяльності, володіння інтегративними навичками.

За визначеними критеріями 3 метою встановлення рівня соціалізації підібрано діагностичні методики:

- для визначення когнітивного критерію - навчальний експеримент, методика «Здібності» Л. Йовайши (М. Врублевська, О. Зиков, 2004), методика соціальної спрямованості М. Рожкова [12];

- для мотиваційно-ціннісного критерію - тематичні бесіди, методика «Зроби оцінку вчинку» для вивчення рівня сформованості моральних цінностей учнів (Е. Курганова, О. Карабанова, 2004), методика автономності Р. Райана (О. Дергачева, Л. Дорфман, Д. Леонтьев, 2004); методика Л. Муренець «Мої орієнтири» (Н. Колодна, Л. Муренець, О. Примак, 2017) [4];

- для особистісно-діяльнісного критерію: аналіз продуктів діяльності, опитувальник Л. Божович, Н. Гуткіної (Коваленко, 2014), експериментальна бесіда для діагностики розвитку комунікації «Невербальна поведінка» (В. Лабунська, 1986), тест-фільм Рене Жиля (Rene Gille, 1959) і С. Розенцвейга (С. Лукин, А. Суворов, 1993) $[5 ; 6]$.

У констатувальному дослідженні взяли участь 113 дітей віком від 11 до 18 років, які навчаються в інклюзивних закладах загальної освіти й закладах спеціальної освіти (контрольна група) Херсонської області. Вибір респондентів цього віку визначено на основі цілі констатувального етапу дослідження, спираючись на теорію Гессена, згідно з якою провідним фактором соціалізації дитини на другому (шкільному) періоді є діяльність навчально-виховного закладу та оточення дитини.

Результати констатувального дослідження довели, що всі показники соціалізації в обох групах знаходяться приблизно на одному рівні нижче середнього. Особливо низькі показники за шкалами: самостійність $(8,78$ \% в ЕГ та $8,93 \%$ в КГ), самовизначення (5,27\% в ЕГ та $5,36 \%$ в КГ), автономність $(10,53 \%$ в ЕГ та $10,72 \%$ в КГ), комунікативна діяльність (7,02\% в ЕГ та 7,15\% в КГ).

Виходячи 3 аналізу результатів констатувального експерименту за критеріями ефективності соціально-психологічного супроводу (когнітивний, мотиваційно-ціннісний та особистісно-діяльнісний), виділили три узагальнені рівні соціалізації дітей з ООП: високий, середній і низький.

Наявність високого рівня соціалізації встановлено лише в незначної кількості дітей з ООП $(8,78 \%$ в ЕГ та $8,93 \%$ в КГ), ці діти володіють інтегративними навичками, відрізняються достатньою автономністю, прийняттям себе, ідентифікацією 3 однолітками, розумінням власних схильностей і здібностей, розумінням моральних цінностей і власних потреб, знають і виконують норми соціальної поведінки в міжособистісному спілкуванні з однолітками та дорослими, мають високу комунікативну потребу, пізнавальну активність і мотивацію до навчання. Вони мають повні знання про власне майбутне й необхідність його планування (таблиця 2).

Середній рівень соціалізації констатований у $36,85 \%$ дітей з ООП ЕГ та $39,28 \%$ в дітей КГ. У цих дітей словниковий запас знаходиться на середньому рівні. Діти мають знання конкретного характеру, не завжди виявляють пізнавальну цікавість до соціального світу, навчальна мотивація нестійка. Мають сформовані міжособистісні стосунки з учнями в класі, але слабко налагоджують нові соціальні зв'язки. Знання про власне майбутне життя неповні. Інтегративні навички сформовані частково (таблиця 1).

Низький рівень установлено в половини респондентів (54,39\% в ЕГ та 51,79\% в КГ). Ці діти характеризуються мовленнєвою інертністю, невисокою пізнавальною активністю, поверховістю 
знань, проблемами 3 поведінкою та комунікацією, мають несформовані практичні й інтегративні навички, недостатній рівень самостійності й автономності, низький рівень навчальної мотивації. У них виявлено поверховність знань про власне майбутне, уявлення випадкові, нестійкі (таблиця 1).

Таблиця 1

\section{Рівні соціалізації дітей до впровадження методики соціально-психологічного супроводу (у \%)}

\begin{tabular}{|c|c|c|}
\hline $\begin{array}{c}\text { Рівні со- } \\
\text { ціалізації }\end{array}$ & $\begin{array}{c}\text { Експерименталь- } \\
\text { на група } \\
\text { (учні закладів } \\
\text { середньої освіти) }\end{array}$ & $\begin{array}{c}\text { Контрольна група } \\
\text { (учні спеціальних } \\
\text { шкіл) }\end{array}$ \\
\hline Високий & 8,78 & 8,93 \\
\hline Середній & 36,85 & 39,28 \\
\hline Низький & 54,39 & 51,79 \\
\hline
\end{tabular}

Таким чином, результати дослідження рівня соціалізації дітей з ООП дали змогу створити повну психологічну картину й дали підстави констатувати необхідність розробки та впровадження методики соціально-психологічного супроводу таких дітей в умовах освітнього процесу.

Основу структури методики соціально-психологічного супроводу становили базові концептуальні положення: когнітивний, діяльнісний, особистісно-орієнтований, мотиваційно-ціннісний і компетентнісний підходи, які обумовили зміст основних компонентів методики: змістового (цілі, завдання, принципи, напрями); функціонального (етапи, форми, методи та технології); оціночного (критерії, рівні).

Методику реалізовано за допомогою взаємозв'язку занять методичних об'єднань центру 3 роботою на основі кейсів (конкретних соціальних психологічних ситуацій, які надавалися учням для розв'язання та закріплення знань, отриманих на заняттях у школі, з метою формування в них основних компетентностей соціалізації.

Методика соціально-психологічного супроводу на основі кейсів дає можливість ставити перед учнями завдання й поетапно досягати результату їх виконання за рахунок вирішення проблемної ситуації.
Основна мета методики - створення психологічних умов на заняттях і в позакласній роботі для цілеспрямованого, особистісно орієнтованого процесу формування в учнів соціальних компетентностей і м'яких технологій, що забезпечить їхню успішну соціалізацію.

Формувальний експеримент проводився в 3 етапи. На першому етапі визначено структуру методичного забезпечення соціально-педагогічного супроводу: науково-методична та педагогічна рада шкіл, методичні об'єднання вчителів-предметників, піклувальна рада, представники соціальних служб і батьківський університет.

Окремо створено команду супроводу та визначено основні форми іiі діяльності: діагностичну - усебічне вивчення дитини 3 урахуванням первинного порушення; прогностичну - визначення напрямів корекційної роботи, складання індивідуальної програми розвитку, прогнозування результатів корекційного й освітнього впливу; корекційну упровадження особистісно орієнтованих програм навчання та реабілітації; проведення корекційно-розвивальних занять; інформачійно-консультативно-просвітницьку - своєчасне й переконливе інформування батьків, педагогічний колектив про проблеми дітей і труднощі в навчанні; тренінги підвищення кваліфікації для фахівців закладів.

На другому етапі здійснювався соціально-психологічний супровід дітей за допомогою кейсів 3 урахуванням сфер їхньої соціалізації (провідна діяльність, спілкування, самосвідомість) за такими напрямами: розвиток провідної діяльності; розвиток індивідуально-особистісних i соціально-поведінкових якостей дитини, міжособистісних стосунків і комунікативної сфери; формування особистісного та професійного самовизначення, розвиток мотиваційної сфери й самосвідомості випускників закладу.

Основними методами роботи команди супроводу на другому етапі експерименту були кейс-метод, індивідуальні бесіди, пояснення; консультації, корекційні заняття, перегляди відеоматеріалів 3 проблеми, ігри-драматизації, тренінгова робота, доручення, флешмоби, робота гуртків і факультативів, створення дитячих шкільних організацій.

Рівні соціалізації дітей з ООП контрольної та експериментальної груп (у \%) на формувальному етапі експерименту демонструє таблиця 2.

Таблиця 2

Рівні соціалізації дітей з ООП контрольної та експериментальної груп (у \%)

\begin{tabular}{|c|c|c|c|c|c|c|}
\hline \multirow{2}{*}{ Рівні } & \multicolumn{3}{|c|}{$\begin{array}{c}\text { Експериментальна група } \\
\text { (учні закладів середньої освіти) }\end{array}$} & \multicolumn{3}{c|}{$\begin{array}{c}\text { Контрольна група } \\
\text { (учні спеціальних шкіл) }\end{array}$} \\
\cline { 2 - 7 } & конст. експ & контр. експ & $\mathbf{t} / \mathbf{p}$ & конст. експ & контр. експ. & t/p \\
\hline Високий & 8,76 & 35,09 & $2,6 / 0,01$ & 8,93 & 16,08 & $0,61 / 0,05$ \\
\hline Середній & 36,85 & 54,39 & $1,9 / 0,05$ & 39,28 & 39,28 & - \\
\hline Низький & 54,39 & 10,52 & $4,4 / 0,001$ & 51,79 & 44,64 & $0,79 / 0,05$ \\
\hline
\end{tabular}


В ЕГ визначено статистично значущі показники: значно збільшилася кількість дітей з високим рівнем соціалізації (від 8,76\% до 35,09\%); значно зменшився показник дітей, які мали низький рівень (від 54,39\% до 10,52\%).

Рівень соціалізації в дітей контрольної групи практично не змінився. Значного покращення в представлених показниках усіх рівнів не виявлено. Низький рівень мають 51,79\% дітей на початку констатувального експерименту й 44,64 \% дітей після його закінчення $(\mathrm{t}=0,79 ; \mathrm{p} \geq 0,05)$.

У два рази збільшився показник успішності в навчальній діяльності дітей ЕГ (p $\leq, 0,001)$, підвищився рівень розвитку інтегративних навичок (від 34,1\% до 87,3\%); збільшилися середні показники соціальної активності (від 61,8\% до 88,7\%) і моральності (від $39,1 \%$ до $88,7 \%$ ), у 2,5 рази підвищився рівень сформованості мотиваційної сфери дітей з ООП ( $\mathrm{p} \leq, 0,001)$. Значно підвищився рівень самостійності й професійного самовизначення старшокласників закладів середньої освіти: випускники КГ обрали професію та продовжують навчання. Більше половини 3 них $(56 \%)$ стали студентами технікумів і коледжів, 20\% - професійних ліцеїв, $24 \%$ - вишів України.

Отже, отримані результати дослідження довели ефективність упровадження методики соціально-психологічного супроводу, іiї здатність забезпечити повноцінну соціалізацію дитини 3 ООП в умовах інклюзивного навчання в закладах середньої освіти.

Подібні дослідження представлено в працях українських дефектологів. Так, у роботі Ю. Бистрової, І. Ананьєва наведено методику соціально-психологічного супроводу осіб з інтелектуальними порушеннями 3 метою формування в них операційної компетентності під час «включеного працевлаштування» та супроводу на соціальному підприємстві. Автори використовують інтерактивні методи роботи з особами з ООП, практичну підготовку й проблемні реальні ситуації спілкування для навичок їх вирішення (I. Ананьєв, Ю. Бистрова, 2021) [1]. У дослідженнях І. Іванченко представлено методики соціального супроводу випускників спеціальних шкіл 3 метою формування в них уявлень про майбутню родину й розвитку відповідних соціальних компетентностей. Авторка впроваджує в практику роботи 3 підлітками, що мають інтелектуальні порушення, ігри-драматизації, тренінги, обговорення ситуацій після перегляду фільмів на задану тематику (А. Іваненко, 2015) [3]. Але автори розглядають окрему категорію дітей з особливими освітніми потребами, а саме 3 інтелектуальними порушеннями. Соціально-педагогічний супровід дітей 3 порушеннями зору розглядався в роботі Н. Колодної. Авторка наполягає на комплексному поєднанні соціального й реабілітаційного складників супроводу. Представлена нами авторська методика використання конкретних соціальних ситуацій для формування соціальних компетентностей у підлітків відрізняється від традиційних методів, представлених у дослідженнях українських учених, тим, що під час розв'язання кейсів учнями в учителів $\epsilon$ можливість одночасно формувати будь-яку соціальну компетентність і контролювати рівень її сформованості в підлітка. Крім того, уперше в практиці корекційної освіти розвивальним середовищем для формування компетентностей нами заявлено не тільки корекційні заняття, а й позашкільну освіту.

Висновки. На підставі теоретичного аналізу спеціальної та соціальної психологічної літератури з'ясовано, що соціально-психологічний супровід $є$ системою послідовної, комплексної, соціально спрямованої діяльності команди фахівців, яка забезпечує процеси індивідуалізації особистості учня, створює умови для його самовизначення за рахунок власних можливостей і здібностей, захищає права учня. На основі теоретичного аналізу й узагальнення наукової психологічної літератури визначено показники ефективності соціально-психологічного супроводу, критерії (когнітивний, мотиваційно-ціннісний та особистісно-діяльнісний) і рівні соціалізації дітей з ООП (високий, середній і низький), розроблено методику соціально-психологічного супроводу таких дітей. Доведено ефективність впровадження методики в закладах середньої освіти. Результатом реалізації методики соціально-психологічного супроводу визначено показники професійного самовизначення випускників: їхній успішний вступ до вищих навчальних закладів III-IV рівнів акредитації.

Подальшого вивчення потребують питання створення команди комплексного соціально-психологічного супроводу осіб з особливими освітніми потребами на різних етапах їхнього навчання в закладах освіти 3 метою формування їхніх особистісних якостей, соціальних і навчальних компетенцій і міжособистісних стосунків, a також питання напрямів соціально-психологічного супроводу осіб з особливими освітніми потребами, зокрема профорієнтаційного напряму, напряму міжособистісної взаємодії та спілкування й напряму навчальної діяльності. 


\section{ЛІТЕРАТУРА}

1. Ананьев И.В., Быстрова Ю.А. Включение лиц с ментальными нарушениями в профессионально-трудовую деятельность (опыт работы социального предприятия «Особая сборка»). Москва : Общество с ограниченной ответственностью «Издательско-полиграфический центр «КАРО», 2021. 144 с.

2. Быстрова Ю.А. Методика коррекционной работы по формированию коммуникативной компетентности у подростков с ОВЗ. Проблемы современного педагогического образования. 2021. № 70-2. C. $370-375$.

3. Іваненко А.С. Формування уявлень про майбутню сім'ю як напрямок соціалізації розумово відсталих підлітків. Науковий часопис Національного педагогічного університету імені М.П. Драгоманова. Серія 19 «Корекційна педагогіка та спещіальна психологія». 2015. Вип. 30. С. 230-236.

4. Колодна Н.А., Бистрова Ю.А. Проблема комплексної реабілітації дітей з порушеннями зору в умовах закладів нового типу. Вісник. 2008. С. 42-48.

5. Лабунская В.А. Невербальное поведение (социально-перцептивный подход). Ростов : Изд-во Ростовск. ун-та, 1986. С. 121-126.

6. Лукин С.Е., Суворов А.В. Тест рисуночной ассоциации Розенцвейга (руководство по использованию). Санкт-Петербург, 1993. 62 с.

7. Попович І.С. Психологія соціальних очікувань особистості: методологія, теорія і практика : навчально-методичний посібник. Херсон, 2019. 234 с.

8. Синьов В.М., Матвєєва М.П., Хохліна О.П. Психологія розумово відсталої дитини. Київ : Знання, $2018.345 \mathrm{c}$.

9. Основи теорії виховання / В.М. Синьов, О.І. Пометун, В.І. Кривуша, М.О. Супрун. Київ : РВ КІВС, 2000. $234 \mathrm{c}$.

10. Drozd L.V., Bystrova Yu.O. Особливості комунікації підлітків з інтелектуальними порушеннями в міжособистісних стосунках. Insight : the psychological dimensions of society. P. 123-133.

11. De Verdier K. Children with blindness: Developmental aspects, comorbidity and implications for education and support. Stockholm University, Faculty of Social Sciences, Department of Special Education, 2018. $124 \mathrm{p}$.

12. Kovalenko V., Bystrova Y., Sinopalnikova N. (2021). Características de compreensão e atitude emocional em relação às normas morais e sociais de alunos com deficiência intelectual. Laplage Em Revista. 2021. № 7 (3A). 2021. P. 575-588. URL: https://doi.org/10.24115/S2446-6220202173A1460p.575-588

13. Opie J. Educating students with vision impairment today: Consideration of the expanded core curriculum. British Journal of Visual Impairment. Volume 36. Issue 1. P. 75-89.

14. Suzanne H. Verver, Mathijs P.J. Vervloed, Steenbergen B. Facilitating Play and Social Interaction between Children with Visual Impairments and Sighted Peers by Means of Augmented Toys. Journal of Developmental and Physical Disabilities. 2020. Volume 32. P. 93-111.

15. Rene Gille. Le test-film (french) paperback. 1959. January 1.56 p.

\section{REFERENCES}

1. Ananyev, I.V. (2021) Vklyuchenie lits s mentalnymi narusheniyami v professionalno-trudovuyu deyatelnost (opyt raboty socialnogo predpriyatiya "Osobaya sborka") [Integration of persons with mental disorders into professional and labor activities (experience of the social enterprise "Osobaya sborka")]. Moscow : LTD "Publishing and Printing Center" "KARO" [in Russian].

2. Bystrova, Y.A. (2021) Metodika korrekcionnoj raboty po formirovaniyu kommunikativnoj kompetentnosti u podrostkov s OVZ [Methods of correctional work on the formation of communicative competence in adolescents with disabilities]. Problems of modern pedagogical education, № 70-2 [in Russian].

3. Ivanenko A.S. (2015) Formuvannya uyavlen pro majbutnyu simyu yak napryamok socializaciï rozumovo vidstalih pidlitkiv [Formation of ideas about the future family as a direction of socialization of mentally retarded adolescents]. Scientific journal of the National Pedagogical University named after M.P Drahomanov. Series 19: Correctional pedagogy and special psychology. №30, 230-236 [in Ukrainian].

4. Kolodna, N.A., Bistrova, Y.A. (2008) Problema kompleksnoyi reabilitaciyi ditey z porushennyami zoru $\mathrm{v}$ umovah zakladiv novogo tipu. [The problem of comprehensive rehabilitation of children with visual impairments in the institutions of a new type]. Bulletin, 42-48 [in Ukrainian].

5. Labunskaya, V.A. (1986) Neverbalnoye povedeniye (socialno-perceptivnyj podhod) [Nonverbal behavior (social-perceptual approach)]. Rostov : Rostov University Publishing [in Russian].

6. Lukin S.E., Suvorov A.V. (1993) Test risunochnoj associacii Rozencvejga (rukovodstvo po ispolzovaniyu). [Test of the Rosenzweig drawing association (guidance on the use)]. Saint Petersburg [in Russian].

7. Popovych, I.S. (2019) Psihologiya socialnih ochikuvan osobistosti: metodologiya, teoriya i praktika: 
navch-metod. posib. [Psychology of social expectations of the individual: methodology, theory and practice: teaching method. manual]. Kherson [in Ukrainian].

8. Sinyov, V.M., Matveeva, M.P., Khokhlina, O.P. (2018) Psihologiya rozumovo vidstalö ditiny [Psychology of a mentally retarded child]. Kyiv : Knowledge [in Ukrainian].

9. Sinyov, V.M., Pometun, O.I., Kryvusha, V.I., Suprun, M.O. (2000) Osnovi teoriyi vihovannya [Fundamentals of the theory of education]. Kyiv : RV KIVS [in Ukrainian].

10. Drozd, L.V., Bystrova, Yu.O. (2020) Osoblivosti komunikaciï pidlitkiv z intelektualnymy porushennyamy $\mathrm{v}$ mizhosobistisnih stosunkah. [Features of communication of adolescents with intellectual disabilities in interpersonal relationships]. Insight: the psychological dimensions of society. 123-133 [in Ukrainian].

11. De Verdier, K. (2018) Children with blindness: Developmental aspects, comorbidity and implications for education and support. Stockholm University, Faculty of Social Sciences, Department of Special Education. 124 p. [in English].

12. Kovalenko, V., Bystrova, Y., \& Sinopalnikova, N.(2021). Características de compreensão e atitude emocional em relação às normas morais e sociais de alunos com deficiência intelectual. Laplage Em Revista, 7(3A), p. 575-588. URL: https://doi.org/10.24115/S2446-6220202173A1460p.575-588 [in English].

13. Opie, J. Educating students with vision impairment today: Consideration of the expanded core curriculum. British Journal of Visual Impairment. Volume: 36 issue: 1, 75-89 [in English].

14. Suzanne, H. Verver, Mathijs P.J. Vervloed \& Bert Steenbergen (2020) Facilitating Play and Social Interaction between Children with Visual Impairments and Sighted Peers by Means of Augmented Toys. Journal of Developmental and Physical Disabilities. Volume 32, 93-111 [in English].

15. Rene, G. (1959, January 1). Le test-film (french), paperback. 56 p. [in English]. 